[fresh page] [recto or verso]

[cn][ct]5. Who wrote Duke Ellington's music? Authorship and collective creativity in 'Mood Indigo'

\title{
[au]Björn Heile
}

$[\mathrm{txt}]$

Musical copyright law is subtly informed by often tacit aesthetic preferences. For instance, it privileges melody over harmony. As the entry on 'melody' of the Music Copyright Infringement Resource (Columbia Law School and USC Gould School of Law 2014) has it:

[ext]

Melody is overwhelmingly the single most important feature of a musical work in evaluating the merits of copyright infringement claims. The entire corpus of judicial opinions in the area of music copyright infringement dwells on melody as the single most idiosyncratic element of the works in question, and almost entirely the locus of the economic worth of a song. ${ }^{1}$

$[\mathrm{txt}]$

The corresponding entry on harmony only describes the phenomenon in musical terms; its value and relevance in adjudicating copyright infringement claims is not even considered. Indeed, a judgment in a case between the estates of Duke Ellington and Billy Strayhorn (very close to the matters discussed here) argues that ' $[\mathrm{h}]$ armony

\footnotetext{
${ }^{1}$ http://mcir.usc.edu/glossary/M-R/Pages/Melody.html, accessed 14 September 2014.
} 
is a derivative creation almost by definition. A composer generally creates a harmony to accompany a particular melody, as opposed to developing harmony in the abstract.'2 Although this confident pronouncement is only true of a very narrow selection of musical styles (whereas in many others melody largely arises from harmony or is inextricably bound up with it), there are fairly sound reasons for privileging melody over harmony in this way: harmony is often relatively anonymous; note, for instance, the importance of stock harmonic progressions such as I-vi-IV-V in popular music (Moore 2004: 334-35), to say nothing of even more ubiquitous progressions such as in the Blues. While the precise origins of these harmonic phenomena are unclear and they can therefore be legitimately regarded as being in the public domain, the same cannot be said about other widespread harmonic progressions, such as the so-called rhythm changes based on Gershwin's 'I Got Rhythm', which act as the foundation for countless jazz tunes. Composers have claimed copyright for pieces based on rhythm changes without in turn paying royalties to Gershwin (or his estate), on the basis that the tunes are contrafacts (although whether Gershwin was really the first to ever use the progression associated with his song must remain doubtful). Nevertheless, as will be seen, harmony can be a more 'idiosyncratic element' of a composer's or performer's style and more

${ }^{2}$ Tempo Music, Inc. v. Famous Music Corp., 838 F. Supp. 162, Dist. Court, SD New York (SDNY 1993). Significantly, though, the judgment goes on to state that " $\mathrm{t}] \mathrm{he}$ Court is not convinced that harmony is unprotectable as a matter of law. While we agree that melody generally implies a limited range of chords which can accompany it, a composer may exercise creativity in selecting among these chords.' Cf. the very interesting and subtle commentary on Music Copyright Infringement Resource (http://mcir.usc.edu/cases/1990-1999/Pages/tempofamous.html, accessed 2 October 2014), which is rather more musically literate than the judgment itself. 
unequivocally reveal their 'authorial signature' than melody. A commonly cited example in jazz would be the individual harmonic language of pianist McCoy Tyner, which is instantly recognisable, whereas his melodic style is much less characteristic (Givan 2007).

Likewise, copyright is primarily concerned with composition, rather than performance: a tune can be protected by copyright, a particular way of playing or singing it cannot. Indeed, as Auslander (2008: 147-58) discusses in detail, performance is not subject to copyright at all under US law (although he neglects to mention that this is actually an anomaly of the US system, since, for example, under UK law there are performers' rights). As a result, improvisation in particular is relegated to a lower status, if indeed it is recognised at all (the Music Copyright Infringement Resource has no entry on it). A fixed (recorded) improvisation would obtain copyright protection as a musical work, but improvisation as such is not recognised by copyright specifically as a separate artistic activity. Finally, and most importantly for my purposes, copyright recognises the achievement of individual named authors (or composers) but not collective forms of creativity (Frith and Marshall 2013: 18, fn. 14).

Whether legal practice followed and adopted the aesthetic concepts in vogue during the inception of copyright law during the eighteenth and nineteenth centuries, as most commentators appear to (often tacitly) assume, or whether, conversely, it created the basis for the concept of the musical work and for the insistence on originality as its distinguishable criterion, as Anne Barron (2006a) contends, matters relatively little for my purposes. What does matter is that copyright law is not neutral when it comes to aesthetic values: it is informed by aesthetic preferences just as it has an impact on artistic practices (Kretschmer and Kawohl 2013). 
In the following I want to discuss some of the aesthetic ramifications of key concepts surrounding musical copyright law. As a musicologist without legal training, my objective is not to attribute copyright or uncover copyright infringement in particular or, indeed, to debate legal concepts and practice in general, but rather to demonstrate how complex such notions as authorship and originality, on which copyright law rests, can be in musical practice.

My example is drawn from the music of Duke Ellington, or, to avoid a simplistic attribution of authorship, music associated with Duke Ellington. This is hardly a radical test case of a musician or group of musicians for whom the very idea of copyright is anathema and where there is hardly any overlap between the values enshrined in copyright law and those held by the musicians and the communities in which they are operating. On the contrary, Ellington is as close to a traditional authorial figure as one can get in the field of jazz and popular music. He is routinely considered as America's or the twentieth-century's greatest composer, an accolade which does not seem to allow any doubts about the authorship of 'his' works or their originality. Unlike a lot of modern jazz, which primarily results from the creative and often improvised interactions between individuals in a collective, the music played by the Duke Ellington Orchestra was largely or fully notated, and the scores (or 'book' as it is often called in big band parlance) were mostly composed by Ellington. This puts the band at one extreme within the overall spectrum of big band swing. Count Basie's band, for instance, relied on generally simpler arrangements, so-called 'head arrangements' (because they can be remembered without notes) often based on riffs simple rhythmic motifs which could be sung to musicians or communicated in verbal instructions without the need for notation - and placed a greater emphasis on improvisation (DeVeaux and Giddins 2009: 215-16). Other bands relied on 'books' 
which had, however, little to do with their leaders: a large proportion of the repertoire of many big bands during the swing era of the 1930s consisted of the work of such composers and arrangers as Fletcher Henderson. Indeed, one of the most interesting features of a crucial event in the history of big band swing, the 'battle of the bands' at the Savoy Ballroom on 11 May 1937, in which Chick Webb's band defeated Benny Goodman's, is that both played a number of the same arrangements by Henderson as well as Edgar Sampson who worked for both bandleaders (Giddins 1998: 139-40). ${ }^{3}$ In other words, what is unusual about the Duke Ellington Orchestra is not that they played from scores (although they may have relied on them more than many other bands), but that their repertoire was so dominated by the work of their leader. Partly as a result, that work is also clearly associated with Ellington's name and established his fame - whereas Henderson, despite being one of the most influential composers in the history of jazz, remained a comparatively obscure figure known only to jazz fans and experts.

Yet, despite the importance of Ellington's individual stylistic signature for the music of his Orchestra, it can be very difficult to identify in detail what exactly Ellington contributed to the music that is associated with his name and often registered to him. Some of the most astute thoughts about Ellington's legacy come from his biographer James Lincoln Collier. Considering first his work as a songwriter he comments:

[ext]

\footnotetext{
${ }^{3}$ Ken Burns's influential, if controversial, TV documentary Jazz (Burns 2001) memorably dramatises the battle by contrasting both bands' performances of Sampson's 'Don't Be That Way' - incidentally a composition based on 'rhythm changes'. The only band to comprehensively defeat Webb's was Ellington's, by the way.
} 
[T]he central melodic ideas of virtually all of Ellington's best known songs originated in somebody else's head. 'Black and Tan Fantasy', 'Black Beauty', and 'East St Louis Toodle-Oo' were primarily the work of Bubber Miley. 'Creole Love Call' was written by King Oliver; 'Caravan' and 'Perdido' by Juan Tizol. 'Mood Indigo' was worked out mainly by Lorenzo Tio, Jr. 'Do Nothing till you Hear from Me' was adapted from 'Concerto for Cootie', the main theme of which was written by [Cootie] Williams; 'Don't Get Around Much Anymore', 'I Let a Song Go Out of My Heart', and 'I'm Beginning to See the Light' came from Hodges melodies; 'In a Sentimental Mood', 'Sophisticated Lady', and 'Prelude to a Kiss' were adapted from Otto Hardwick melodies; 'I Got It Bad' was adapted from something Mercer [Ellington] wrote; 'Satin Doll' and 'Take the "A" Train' were written by Billy Strayhorn. Of all the songs on which Ellington's reputation as a songwriter and his ASCAP royalties as well - is [sic] based, only 'Solitude' appears to have been entirely his work (Collier 1993: 302).

[txt]

Evaluating Ellington's status as a composer he writes: [ext] By 'composer' we usually mean somebody who makes up more or less complete works of music that are written down or, today, at least organized on a piece of tape by the creator. Ellington rarely wrote out a composition in complete form, and in many, perhaps most, instances, the work existed on paper only in scraps and pieces, which have long since disappeared.

Furthermore, like that of the songs, the provenance of much of the work is obscure. The men in the sections worked out a lot of the voicings, although 
in the main from chords supplied by Ellington. Tom Whaley and Juan Tizol [Ellington's main copyists] often made alterations as they extracted the parts. A great many contrapuntal or answering lines were suggested by members of the band ... Phrases, snatches of melody, came from everywhere. And, of course, after 1939 Billy Strayhorn contributed a great deal. (Collier 1993: 303).

$[\mathrm{txt}]$

Will Friedwald (quoted in Santacroce 2014) makes a similar observation, homing in, however, on the crucial question of credit:

[ext]

Irving Drake described Ellington's orchestra as a musical kibbutz, in that it was this kind of collective. There were, say, you know, five or six really talented composers apart from Ellington in that orchestra and often, you know, they worked with Ellington in developing his tunes and he would work on developing things that they came up with, and there was a lot of back and forth in it. To a great degree, they were credited and compensated and to a certain degree, they were not.

$[\mathrm{txt}]$

When it comes to credit and compensation, the most aggrieved party was arguably Billy Strayhorn, mentioned only in passing by Collier above. Strayhorn was a composer and arranger of a similar stature to that of Ellington - some of the Orchestra's greatest hits, including their signature tune 'Take the "A" Train' are his but he has arguably never been given his full due, either in fame or fortune. The received wisdom was that Strayhorn and Ellington collaborated so closely and that their styles were so similar - or rather that they were able to mimic each other's style 
so perfectly (more often Strayhorn imitating Ellington than the other way around) that their individual contributions were indistinguishable. The record was put straight in an important book by Walter van de Leur who, through a meticulous analysis of both composers' styles and working methods, argues convincingly that Strayhorn had a distinct voice and approach as a composer and that his contributions can be traced quite precisely - and that they indeed often remained anonymous and uncredited, either deliberately or through the negligence of the company employed, Tempo Music Inc. (van de Leur 2002: 100-116). ${ }^{4}$ In the process, van de Leur (2002: 107) dispels some of the myths, partly also propagated by Collier: 'The perennial anecdotes about music written on shirtsleeves notwithstanding, Ellington (like Strayhorn), for the larger part of his career, relied on written scores and parts, a practice he started somewhere in the early thirties as a result of the increasing complexity of his music and the growing number of voices in his band. ${ }^{5}$

I want to concentrate on a much earlier period in Ellington's career, before Strayhorn joined the enterprise and muddied the waters even further. My focus is on 'Mood Indigo' (1930). The piece was the Orchestra's first hit which made them famous, although their reputation and exposure had increased gradually during the preceding three years when they were employed at the Cotton Club, the formative period for the band and for Ellington as composer and leader. In his autobiography, the Duke, who had a penchant for tall tales as much as for great tunes, summed up the composition of the piece thus (Ellington 1976: 78-79):

\footnotetext{
${ }^{4}$ It is therefore no surprise to hear of cases contested between the estates of Ellington and Strayhorn, such as the one cited above in note 1.

${ }^{5}$ Van de Leur's research is focused on the Duke Ellington Collection at the Smithsonian. Unfortunately, I have not been able to access the Collection for this research.
} 
[ext]

[In 1930], in the fall, we had a six-piece recording date.... On this occasion, as usual, the night before was the time for me to write and think music. I already had three tunes and, while waiting for my mother to finish cooking dinner, I began to write a fourth. In fifteen minutes, I wrote the score for 'Mood Indigo'. We recorded it, and that night at the Cotton Club, when it was almost time for our [regular radio] broadcast, Ted Husing, the announcer, asked, 'Duke, what are we going to play tonight?' I told him about the new number, and we played it on the air, six pieces out of the eleven-piece band. The next day, wads of mail came in raving about the new tune, so Irving Mills [the band's manager, publisher and occasional lyricist] put a lyric on it, and royalties are still coming for my evening's work more than forty years later.

\section{[txt]}

In an interview (quoted in Nicholson 1999: 113), he further clarified that Mills had changed the title to 'Dreamy Blues' to give it wider appeal, although it soon reverted. It was recorded first for Okeh Records on 14 October 1930, then for Brunswick on 17 October and a third time, with a larger band, for RCA Victor on 10 December 1930, although the band is given different names each time (the first two also appeared under the original title 'Dreamy Blues'). ${ }^{6}$ To complicate matters, the recordings are

\footnotetext{
${ }^{6} \mathrm{http}: / / w w w . d e p a n o r a m a . n e t /$ (accessed 19 September 2014). There is a little uncertainty about dates. According to Ellington's own account (quoted above), the piece was recorded and broadcast live on the same day, although most other accounts suggest that the broadcast took place on the following day (then, again, it is also possible that it occurred after midnight, therefore technically falling on the next day, although informally taking place on the same night). This need not concern us further.
} 
significantly different (my observations are based on Brunswick 4952, the second and most widely disseminated recording).

Somewhat contradicting his own account of a composition that was quickly jotted down, he gave it a loose programme on another occasion (quoted in DeVeaux and Giddins 2009: 227):

[ext]

It's just a little story about a little girl and a little boy. They're about eight and the little girl loves the little boy. They never speak of it, of course, but she just likes the way he wears his hat. Every day he comes by her house at a certain time and she sits in her window and waits.... Then one day he doesn't come. 'Mood Indigo' just tells how she feels.

[txt]

What Ellington, not uncharacteristically, fails to acknowledge in any of these accounts is that the piece or the inspiration for it was not entirely his. As practically all commentators point out, he learned the melody for the piece from his clarinettist Albany (Barney) Bigard. As was already pointed out, this was common practice in Ellington's band, in which many of the catchiest melodies were provided by the players associated with them. Bigard (1988: 64-65) claimed, however, that he had to sue Ellington to get a cut of the royalties: 'We didn't think anything of it and, all of a sudden, it began to get popular and that was that. I missed the boat for 28 years on royalties. I didn't get a dime. It was all under Ellington's and Mills's names'. Although he has received credit, he claimed to have sold the rights to Mills 'for twenty-five or fifty dollars' and that he received royalties only following the court case (of which there aren't any known records) (Bigard 1988: 65). 
In any case, the story doesn't quite end there. Bigard (1988: 64) further claimed to have learned the tune from his teacher, Lorenzo Tio (Jr.):

[ext]

My old teacher, Lorenzo Tio, had come to New York and he had a little slip of paper with some tunes and parts of tunes that he had written. There was one I liked, and I asked him if I could borrow it. He was trying to interest me in recording one or two maybe. Anyway, I took it home and kept fooling around with it. It was just the second strain. There was no front part on what Tio gave me. I changed some of it around, for instance the bridge on the second strain, and got something together that mostly was my own but partly Tio's.

[txt]

Indeed, Al Rose claims that the melody was the signature tune of Armand Piron's orchestra, of which Tio was a member (quoted in Tyle 2014). In that case, Tio or his heirs would presumably deserve credit and a share of the proceeds as well. Indeed, his daughter claimed to have had 'a business arrangement' with Ellington (Tyle 2014), although what that amounted to is anyone's guess.

As if the origin and authorship of the tune were not complicated enough, it is not entirely certain what exactly he contributed. The piece is in an ABA' (or ternary) form, with a contrasting middle section sandwiched between statements of the main melody or theme. Unusually for Ellington, who tended to prefer to modulate to often distant keys in his middle sections (with a particular preference for the key of the flattened sixth, also a favourite of romantic composers such as Schubert), the middle section stays in the same key. Indeed, again uncharacteristically, it features much the same harmonic progression as the outer sections, making the piece appear like a set of 
variations or succession of choruses ${ }^{7}$ (although the contrast in melodic material, character and instrumental sound makes the three-part division clear enough).

In the quotation above, Bigard speaks of a 'second strain' which suggests that he is referring to the B section, although the term is not very clear. He goes on to say that:

[ext]

Duke figured out a first strain and I gave him some ideas for it too. He wrote out a three-part harmony for the horns, we added my second strain and recorded it. [Arthur] Whetsol [the trumpeter] had the lead, I had the second and [Joe] Ticky Sam [Nanton, the trombonist] had the third. (Bigard 1988, 64).

[txt]

While this confirms Bigard's (or Tio's) authorship of the B section, Bigard also makes a partial claim for the A section. However, his recollection obviously cannot be trusted: if with 'lead', 'second' and 'third' he is referring to the voices in the opening three-part harmony, he is clearly misremembering - all commentators are agreed that the clarinet plays the bottom part, and this is unmistakable on the recording. How far his testimony can be trusted in other matters is an open question.

In any case, the admission that he contributed the 'second strain', presumably the B section, relativises the importance of his contribution substantially (his partial claim for the A section notwithstanding). Songs or pieces are typically identified by

\footnotetext{
${ }^{7}$ Since jazz standards are frequently based on the choruses of Tin Pan Alley songs, the term 'chorus' tends to refer to the pattern established by the opening of a piece, which is typically 32 bars long and in a regular chord progression, which is then repeated. The melodic material of the opening may or may not be taken up in later choruses, although it's typically restated at the end.
} 
their A section and this is where we would normally look for a tune - name any Ellington hit number and what comes to mind is its opening melody. On one level, 'Mood Indigo' is no exception: the A section (see Figure 5.1) ${ }^{8}$ is far more memorable and justly famous; the B section (see Figure 5.2), by contrast, is undeniably attractive and effective but not particularly 'special'. The problem is, however, that the A section does not qualify as a 'tune'. Almost uniquely for a jazz standard, it is, as Bigard hinted at, in fact a three-part chorale, and, although the top part functions as a melody, its effect is almost solely due to the accompanying harmony.

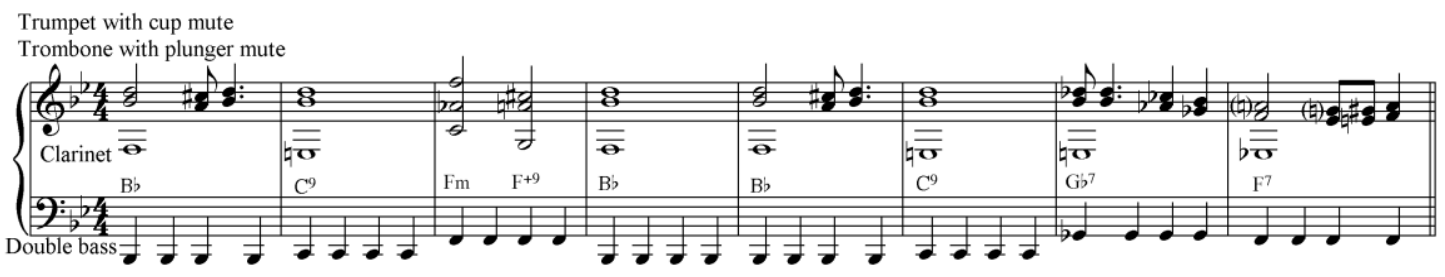

Figure 5.1: Ellington/Bigard, 'Mood Indigo', beginning, Brunswick 4952, 17 October 1930

The B section, by contrast, conforms much more to standard expectations of a 'tune'. A feature on the piece on National Public Radio seemingly correctly identifies Bigard's contribution as exactly that melody (Santacroce 2014). By contrast, DeVeaux and Giddins (DeVeaux and Giddins 2009: 227) appear to identify what they simply call 'the melody' as the top line of the chorale of the A section when they state that Ellington 'cast the whole thing in a daringly original arrangement' (which can

\footnotetext{
${ }^{8}$ The transcription of example 1 follows Darcy James Argue http://musicalexchange.carnegiehall.org/profiles/blogs/arranging-ellington-theellington-effect (accessed 18 September 2014). Argue corrects the influential transcription by Gunther Schuller (1986: 343). Presumably following Irving Mill's original publication of the sheet music version of the tune, many transcriptions and arrangements are in A flat major, but the original is definitely in the more common B flat major. I wish to thank Jamie Fyffe, Peter Elsdon and Bill Sweeney, whose sharp ears confirmed the accuracy of Argue's transcription. Figure 5.2 is my transcription.
} 
only refer to the opening), also suggesting that he added 'a memorable bridge'. 9 Despite these discrepancies, no-one seems to admit to any uncertainty as to what is meant by the 'tune' or 'melody' that Bigard contributed. Interestingly, the vocal version, recorded in 1940 with Ivie Anderson as singer, does not feature the melody of the B section at all; after a short piano introduction, Anderson sings the top line of the chorale accompanied by lush horns (Ellington's band had grown to what became full big band line-up in the intervening years).

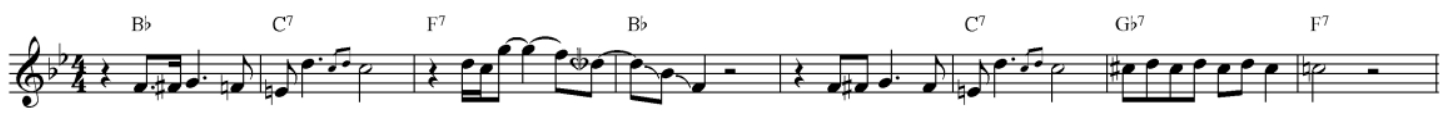

Figure 5.2: Ellington/Bigard, 'Mood Indigo', B section, Bigard’s solo, Brunswick 4952, 17 October 1930

If Bigard's (or Tio's) contribution did consist of the melody of the B section as I assume, their role would be rather limited. Despite its undeniable charms, the clarinet tune is fairly unremarkable. Since the B section is based on the same harmonies as the A section, it appears rather like an instrumental solo on a chorus (and is often described as such). ${ }^{10}$ These solos are often improvised, and in that case

\footnotetext{
9 'Bridge' refers to a contrasting section within the opening theme, in this case bars 912 (coming after the bars shown in Figure 5.1), before the opening is restated (the theme is a classic AA'BA form, albeit in 16 slow, rather than the conventional 32 uptempo bars). The section, which features a dialogue between trumpet and trombone which loosens the chordal texture of the opening, is indeed 'memorable'. The term 'bridge' is sometimes used more loosely to refer to any kind of contrasting or transitional section, potentially even an entire middle section, but, given their standing, it is safe to assume that DeVeaux and Giddins are employing the term in its technical sense here. What makes them think that Bigard contributed the first eight bars and Ellington contributed the bridge is anyone's guess, though.

${ }^{10}$ A good example here is Schuller (1989, 307, fn. 41) who, when discussing solos which may not be entirely 'spontaneous' (i.e. improvised), comments that: 'a
} 
the improvising musician has no rights at all. Many comparable examples, from the work of the Duke Ellington Orchestra and others, come to mind. Maybe the most compelling is Ray Nance's trumpet solo on Billy Strayhorn's 'Take the "A" Train'. This solo became such an integral part of the piece that it was usually repeated almost note by note in every performance, whether by Nance or his successors in the Ellington band, notably Cootie Williams. There is no evidence that anyone else (including Strayhorn) wrote the solo, so the most likely assumption has to be that Nance improvised or wrote it. This makes the solo a part of the performance practice of the piece, rather than its composition, and, consequently, Nance has not been credited, although he or his descendants could presumably claim copyright as a (performing) composer. ${ }^{11}$ For a listener, however, his contribution to "Take the "A"

previously worked-out "solo" might have been so successful - as in the case of Barney Bigard's famous clarinet chorus in Mood Indigo - that it could not be improved upon and thus would become an integral part of the composition'. Note that Schuller seems to assume that Bigard's solo was an addition to the piece during performance, not its starting point (he never mentions the tune's genesis) and that he indeed regards it as a 'chorus'. He may have worked on the first Okeh recording, in which Bigard's solo is followed by one by Arthur Whetsol (trumpet), thus strengthening the impression of a succession of solo choruses, rather than a tripartite form with a solo in the middle section, or potentially the later Victor recording, in which the sequence is reversed - although that later recording is usually regarded as inferior. The Brunswick recording is unique in featuring only a solo by Bigard. ${ }^{11}$ Indeed the fact that Williams and other trumpeters typically copy Nance's solo is usually regarded as an act of homage, upholding Nance's 'moral right' (in an untechnical sense) as author in an informal, communitarian way. A counterexample can be seen in the dispute between guitarist Pat Metheny and saxophonist Kenny G about the latter's appropriation of the music of Louis Armstrong. Essentially, without using the term in its legal sense, Metheny claims that Kenny G has breached the moral rights inherent in Armstrong's legacy. See Whyton (2013: 57-81). 
Train' is not substantially different from Bigard's to 'Mood Indigo': both play instrumental solos whose melodies contribute to the character of the piece in question. Yet, in Bigard's case the melody came at the beginning of the creative process, in Nance's near the end - more than that, considering the distinction between composition and performance informing musical copyright, Nance's solo is not even a part of 'Take the "A" Train' at all, even though millions of people have got to know the piece with this solo and may love it partly because of that.

Returning to 'Mood Indigo', what Ellington did was to write a piece around Bigard's (or Tio's) melody. This method contrasts with other pieces co-written with his band members. For instance, 'Caravan' is clearly based on its haunting opening melody, contributed by valve trombonist Juan Tizol. Similarly, the main theme in 'Concerto for Cootie' was suggested to Ellington by the composition's dedicatee, trumpeter Cootie Williams. In 'Mood Indigo', by contrast, Ellington seems to have built a piece around the melody which only appears in its middle section.

According to all accounts, the most original aspect of the piece is its opening chorale. Ellington emphasised the fact that it is indeed an integral three-voice structure, and not a tune with harmonic accompaniment, by having the players perform in front of the band like featured soloists in live or filmed performances (there is a host of footage featuring the piece, from widely different periods and involving various players). But what is even more revolutionary is its arrangement. Here is Ellington's (1976: 80) own account again:

[ext]

When we had made 'Black and Tan Fantasy' with the growl trombone and growl trumpet, there was a sympathetic vibration or mike tone. That was soon after they had first started electrical recording. 'Maybe if I spread those 
notes over a certain distance', I said to myself, 'the mike tone will take a specific place or specific interval in there.' It came off, and gave that illusion, because 'Mood Indigo' - the way it's done - creates an illusion. To give it a little additional lustre for those people who remember it from year ago, we play it with the bass clarinet down at the bottom instead of the ordinary clarinet, and they always feel it is exactly the way it was forty years ago.

\section{$[\mathrm{txt}]$}

At that time, big band arrangement tended to be sectional, pitting reeds (clarinets and saxes) against brass (trumpets and trombones) and typically using instrumental sections in blocks. 'Mood Indigo' was originally scored for a comparatively small band; nevertheless, combining instruments from different families in this manner was already unusual (and became a hallmark of Ellington's style), and the use of mutes adds a particular colour. According to a commonly held view, espoused by David Baker (quoted in Santacroce 2014) and John Edward Hasse (1995: 142), the most original feature is that the arrangement is 'upside down', with the lowest instrument (the trombone) on top. Again, this is actually not quite so clear: many other commentators seem to hear the trumpet carrying the top line; this is very difficult to distinguish, but the register (up to a high F) is very high for a trombone and it is difficult to see how even a star player such as Joe 'Tricky Sam' Nanton could have played it with such control and with soft dynamics. ${ }^{12}$

\footnotetext{
${ }^{12}$ My expert listeners Jamie Fyffe, Peter Elsdon and Bill Sweeney hear the trumpet carrying the top line, as Argue's transcription indicates as well. The portamenti caused by the trombone's slide are the giveaway, which can be identified with the second voice. Hasse (1995: 210) cites Ellington pointing out that sustaining the high D 'haunted trumpet players for many years ... to the extent that they never wanted to
} 
Whatever the exact instrumentation, the arrangement creates a completely unprecedented sound: the brass fragile and soft, the clarinet warm and rich. Overall, the notes are all in a relatively narrow middle range that was perfect for the still relatively rudimentary technology of the time, but, with the exception of the trumpet (which is, however, muted), none of the instruments is playing in its own respective middle range, which can often be relatively dull and inexpressive. (Ellington's oftrepeated claims regarding the 'mike tone' are less clear, however: although such lowfrequency hums are common on old records, I cannot hear anything like that in this recording.)

The way Ellington appears to have approached the task of integrating Bigard's tune was to base the entire composition on its harmonic progression, so that the tune would appear like a solo chorus or one of a sequence of variations. That progression could hardly be simpler: a cadence $\mathrm{I}-\mathrm{ii}-\mathrm{V}-\mathrm{I}$ in B flat Major, followed by a variation as a turnaround to the beginning (I-ii-bVI7-V7) (see Figure 5.1). In Ellington's hands, this basic progression is embellished by a rich and sophisticated chromaticism, which lends the piece its languid and sensuous quality and which is almost entirely lacking in the tune itself. Concentrating on the top line, the first instance of this chromaticism is so inconspicuous as to be hardly noticeable: from its opening D, the melody briefly touches on C sharp, a chromatic neighbour note. This same note becomes more prominent in the following bar when it becomes an additional leading note on dominant harmony, leaning into its goal, the $\mathrm{D}$ of the play the lead part.' This is somewhat confusing, since although the top line does indeed centre on $\mathrm{D}$, thereby providing further confirmation that it is played by the trumpet (contrary to Hasse's own assertion), this is in no way a challenge for a trumpet (although it is for a trombone whose range is generally an octave lower). Hasse does not provide a source. 
ensuing tonic, and, with the previous $\mathrm{F}$, outlining a particularly expressive and sinuous diminished fourth. ${ }^{13}$ Arguably the most radical instance, however, comes two bars later, after a restatement of the opening motif, when the melody slides chromatically downwards, and again the crucial note is $\mathrm{C}$ sharp or, rather its enharmonic equivalent $\mathrm{D}$ flat, this time harmonised with a $\mathrm{G}$ flat dominant seventh chord. This last chord appears entirely foreign in B flat major and it is resolved (if that is the word) by sinking chromatically to the dominant, an F seventh chord. Probably the best explanation is that it is a tritone substitution for $\mathrm{C}$ (this harmony is shared with the B section, but it seems more likely to have started life in the A section, where its chromaticism is more of a piece with the surrounding music). If so, it is an early example, since that phenomenon is largely associated with the bebop of the early 1940s, and it is more typically used as a substitute for the dominant, not ii, or a secondary dominant replacing ii, as in this case.

One striking aspect of Ellington's mastery of chromatic harmony here is its economy. The melody consists of only very few notes, and Ellington gets some of the most astonishing effects by re-harmonising $\mathrm{C}$ sharp (a note that is foreign in the key) and its upper neighbour D. The surprising ways in which the former is coloured harmonically have already been explained, but the latter is also interesting. Although it mostly appears as the third of the tonic B flat major, as one would expect, in the second bar of the tune, it features as the ninth over $\mathrm{C}$ major (II, replacing its minor parallel ii at this point), another surprising and expressive harmonisation, particularly

\footnotetext{
${ }^{13}$ Conventionally, in a dominant-tonic progression such as this, the leading note is the third of the dominant which resolves to the root of tonic. Here, this relation is doubled a third higher, creating added tension. The result is an altered dominant chord.
} 
for the time (these harmonic devices would become more commonplace in later decades). The astonishing arrangement and harmony of this section clearly reveal Ellington as the composer, even if Bigard did contribute the melodic line (which, to repeat, I regard as unlikely; the more persuasive assumption appears to be that he contributed the melody of the contrasting middle section).

In some respects, then, we have come full circle. Although early on I relativised Ellington's claim to authorship of 'Mood Indigo', on the grounds that 'the melody' (whatever that means exactly) was provided by his clarinettist Barney Bigard and/or Bigard's teacher, Lorenzo Tio, later on I suggested that what makes the piece special is clearly Ellington's work. Among these features are the fact that its main theme is a chorale, the way that chorale is arranged and the subtle chromatic harmonies employed. In terms of an aesthetic judgement of originality, these aspects arguably outweigh the 'ownership' of any of the melodies employed, whether it is the top line of the opening chorale or the clarinet solo in the B section. Yet, as the opening quotation suggests, it is the melodic content on which most judgments on copyright hinge, whereas harmony and arrangement are typically afforded a lower status - an assessment that jars with Ellington's artistry or indeed any kind of composition of a sophistication beyond mere tune smithery. As pointed out, the harmony is far more 'idiosyncratic' than any of the melodies. ${ }^{14}$ Likewise, his art is

\footnotetext{
${ }^{14}$ Again, the commentary on Tempo Music vs. Famous Music on the Music Copyright Infringement Resource is worth quoting at length:

[ftnote ext]

The Court's statements raise nice questions too about how musicians create new and derivative musical works, and whether assembling the harmonic and melodic components is, at least for some genres, more simultaneous than the Court's discussion here suggests. It may be worth pondering, for instance,
} 
revealed not least in the subtle arrangement, another craft that is typically afforded a lower status than musical (particularly melodic) invention by copyright law. Note, too, that, if Bigard had improvised the melody of section B or contributed it to the performance rather than the composition proper (as Nance did with his solo to 'Take the "A" Train'), he would have found it extremely difficult to establish copyright claims to that work. More important even than any distinction between the competing claims of melody and harmony, musical invention and arrangement, or composition and performance is the fundamental insight that, when it comes to individual

whether Mozart or Bach conceived their melodic lines independent of the harmonies they set them to. Or, does the relationship between melody and harmony in the conception of Classical works depend more on the genre of the work involved (e.g. Theme-and-variations, fugue) than upon the approach of a particular composer (or group of composers associated chronologically and stylistically)? Is it more likely that a jazz melody sooner than a Classical one would be conceived and fixed independent of a harmonic setting? What holds the attention of listeners when they hear new jazz harmonizations of wellknown tunes; outré settings that wild-eyed church organists (yes, they exist) use to renew shopworn hymn tunes; a series of variations on a well-known theme? What do these examples suggest about the potential value of harmony to the aesthetic and financial value of a musical work? (http://mcir.usc.edu/cases/1990-1999/Pages/tempofamous.html, accessed 2 October 2014)

[ftnote txt]

There is a rare acknowledgement here that questions of musical technique (and therefore what aspects of a style are characteristic and copyrightable) are stylespecific and that generalisations about the role of melody and harmony in music lack any kind of credibility or legitimacy, although the section does not go nearly far enough. Distinctions between classical and jazz music are not nearly fine-grained enough; every period, genre or composer and, in some cases, piece have their specific stylistic conventions. 
contributions to a collective creative effort, there will always be more shades of grey than black and white and unequivocal attribution is more the exception than the rule. Among creative people such as the Duke Ellington Orchestra, ideas would have constantly circulated and the musicians would have spurred one another to ever newer inventions. In other words, all the aesthetic preferences enshrined by copyright as outlined above seem peculiarly ill-suited for this kind of music.

In a celebrated account, the sociologist (and amateur jazz pianist) Harold Becker (2008: 1) argued more than thirty years ago:

[ext]

All artistic work, like all human activity, involves the joint activity of a number, often a large number, of people. Through their cooperation, the art work we eventually see or hear comes to be and continues to be. The work always shows signs of that cooperation. The forms of cooperation may be ephemeral, but often become more or less routine, producing patterns of collective activity we can call an art world.

[txt]

It may come as no surprise that a sociologist would emphasise the collective nature of creativity, but, less predictably, similar views have emerged in psychology, where the notion of 'distributed creativity', according to which 'creativity is embedded in social groups, and ... creative products emerge from collaborative networks' (Keith and DeZutter 2009: 81), has been gaining ground. ${ }^{15}$

There is no absolute contradiction between approaches which prioritise individual achievement and those which emphasise collective endeavour. These are

\footnotetext{
${ }^{15}$ For related approaches in Music, see, for example Born (2005) and Clarke, Doffman and Lim (2013).
} 
complementary perspectives, and musical styles, cultures and practices vary in terms of the relative importance of either side. Nor should the practical difficulties or epistemological uncertainties surrounding creative processes be used as an excuse to deny proper acknowledgement, credit and reward to individual achievements. As my discussion above has shown, it is possible to clarify some of individual original contributions that have gone into a masterwork and lucrative hit tune such as 'Mood Indigo'. As I have also pointed out, there are suggestions that Ellington himself did not always treat his collaborators fairly and such behaviour should not be condoned. Nevertheless, what is required is a change of emphasis from the normative assumption according to which creative products emerge primarily from the work of named individuals, on which copyright is largely based, to one according to which they are primarily the result of collective endeavour, in which individual contributions can often no longer be identified. What such a model could look like in concrete terms is hard to say. Jason Toynbee (Toynbee 2010) has used Reggae as an example of 'social authorship' which has developed largely due to the absence of an effective system of copyright enforcement, arguing for the adoption of a system similar to the GNU General Public License (GPL) used in open source software. Yet, his somewhat utopian depiction of the Jamaican music scene is difficult to reconcile with his own admission of the poverty of musicians and their exploitation by producers who not only retain profits and rights but also credits. Moreover, virtually all of his claims have been comprehensively rebutted by Johnson Okpaluba (2010, 374-86), who has pointed out that 'the lack of an adequate copyright environment and the lack of any direct involvement of the major record companies in Jamaica has meant that the vast majority of pre-1990s recordings and rights have been entirely appropriated by the global major record companies with little or no revenue finding its way back to the 
original artists or producers' $(375-76$, fn. 8$)$, that there is little evidence that the flourishing of Jamaican music is related to the lax copyright regime, that most major artists have welcomed more effective copyright protection, and that the economic and legal structure of the music business is so distinct from that of software engineering so as to invalidate the comparison with the GPL license.

The wholesale rejection of any form of copyright protection seems thus tantamount to throwing out the baby with the bathwater. While Okpaluba's arguments against the adoption of the GPL license in music are clearly well made, this is not to say that a more developed equivalent of the model that takes the economic structures and working practices of the music industry into account may not hold promise in the future, particularly at a time when the primary economic value of recordings is increasingly that of acting as promotion for live performances. In the meantime, a more enlightened and musically informed legal practice that considers all aspects in which creativity finds an original expression, including such means as harmony, arrangement and production, and which recognises performance on a comparable level with composition, would be possible within the confines of the current overall system (for a fuller discussion of possible revisions to British copyright see Barron 2006b and Bently 2009).

To complicate matters further, one way in which Ellington achieved his unique vision and sound was precisely by giving his musicians the freedom and encouragement they needed in order to provide their individual ideas. As is well known, Ellington chose musicians with very distinctive or even idiosyncratic qualities, such as a unique sound (the growl effects produced by Nanton and Whetsol in pieces such as 'Mood Indigo' are cases in point), and he wrote music specifically for them rather than for their instruments, even writing their names rather than the 
instrument in his scores. He was also famously indulgent towards his musicians, rarely reprimanding or disciplining, let alone firing them, and generally paying well. This may go some way in explaining their relative loyalty. Indeed, his leadership style has been the subject of studies in management (for example Humphreys, Ucbasaran, and Lockett 2012). In other words, if Ellington did not always directly and personally create the music played by his Orchestra, he was largely responsible for creating the conditions under which it could be created. What he is credited for in this sense is as a bandleader, more than as a composer, and his name is used more as a brand name than as an authorial signature. This would set him on a par with other bandleaders, such as the aforementioned Benny Goodman, Chick Webb or Count Basie (the two first-named also enjoying high profiles as performers). Ellington's case is, however, more complex since his work as a composer cannot be separated from his role as bandleader or, indeed, his activities as a performer. Ultimately, his artistry is to be found in the way he managed to combine these various roles. As a bandleader, he attracted and inspired some of the most creative musicians of his day, whose work he embraced and made his own (more or less legitimately). Directing them and performing with them clearly honed his compositional style and abilities, and his own compositions are to a certain extent a product of these influences. A sensitive approach to his work needs to be mindful of the different roles Ellington performed and the contributions made by his musicians and other collaborators. This includes a subtle understanding of the inextricable relation between individual authorship and collective or distributed creativity. As I have also pointed out, the music of the Duke Ellington Orchestra is hardly unique in this regard, and in specific ways, all music and indeed artistic activity is subject to these complementary if frequently competing forces. Any discussion of copyright has to be informed by the same principles and 
needs to remain cognisant of the contingency of all claims to individual creative contributions.

\section{[a]BIBLIOGRAPHY}

[bib]

Auslander, Philip (2008), Liveness: Performance in a Mediatized Culture, London: Routledge.

Barron, Anne (2006a), 'Copyright Law's Musical Work', Social \& Legal Studies 15 (1), 101-27.

Barron, Anne (2006b), 'Introduction: Harmony or Dissonance? Copyright Concepts and Musical Practice', Social \& Legal Studies 15 (1), 25-51.

Becker, Howard Saul (2008), Art Worlds, 25th anniversary ed., updated and expanded, Berkeley, CA, London: University of California Press.

Bently, Lionel (2009), 'Authorship of Popular Music in UK Copyright Law', Information, Communication \& Society, 12 (2), 179-204.

Bigard, Barney (1988), With Louis and the Duke: The Autobiography of a Jazz Clarinetist, New York: Oxford University Press.

Born, Georgina (2005), 'On Musical Mediation: Ontology, Technology and Creativity', Twentieth-Century Music 2 (1), 7-36. 
Burns, Ken (2001), ‘Jazz’, PBS.

Clarke, Eric, Doffman, Mark, and Lim, Liza (2013), 'Distributed Creativity and Ecological Dynamics: A Case Study of Liza Lim's “Tongue of the Invisible”, Music and Letters 94 (4), 628-63.

Collier, James Lincoln (1993), Duke Ellington, Macmillan/McGraw-Hill School Pub.

Columbia Law School, and USC Gould School of Law (2014), Music Copyright Infringement Resource: http://mcir.usc.edu (accessed October 1).

DeVeaux, Scott Knowles, and Giddins, Gary (2009), Jazz, New York: W.W. Norton.

Ellington, Duke (1976), Music Is My Mistress, New York: Da Capo Press.

Frith, Simon, and Marshall, Lee (2013), 'Making Sense of Copyright', in Music and Copyright (ed. Simon Frith and Lee Marshall), pp. 1-18, Hoboken: Taylor and Francis.

Giddins, Gary (1998), Visions of Jazz: The First Century, Oxford: Oxford University Press.

Hasse, John Edward (1995), Beyond Category: The Life and Genius of Duke Ellington, New York: Da Capo Press. 
Humphreys, Michael, Ucbasaran, Deniz, and Lockett, Andy (2012), ‘Sensemaking and Sensegiving Stories of Jazz Leadership', Human Relations, 65 (1), 41-62.

Keith, R., and DeZutter, Stacy (2009), 'Distributed Creativity: How Collective Creations Emerge from Collaboration', Psychology of Aesthetics, Creativity, and the Arts, 3 (2), 81-92.

Kretschmer, Martin, and Kawohl, Friedemann (2013), 'The History and Philosophy of Copyright', in Music and Copyright (ed. Simon Frith and Lee Marshall), pp. 21-53, Hoboken: Taylor and Francis.

Nicholson, Stuart (1999), Reminiscing in Tempo: A Portrait of Duke Ellington, Evanston, IL: Northwestern University Press.

Okpaluba, Johnson (2010), “"Free-Riding on the Riddim”? Open Source, Copyright Law and Reggae Music in Jamaica', in Copyright and Piracy (ed. Lionel Bently, Jennifer Davis, and Jane C. Ginsburg), pp. 374-86, Cambridge: Cambridge University Press.

Santacroce, Lou (2014), ‘Mood Indigo', NPR.org. (accessed September 21) http://www.npr.org/2000/11/06/1113561/npr-100-mood-indigo.

Schuller, Gunther (1986), The History of Jazz, New York, Oxford: Oxford University Press. 
Schuller, Gunther (1989), The Swing Era: The Development of Jazz, 1930-1945 (The History of Jazz, vol. 2), New York, Oxford: Oxford University Press.

Toynbee, Jason (2010), 'Reggae Open Source: How the Absence of Copyright Enabled the Emergence of Popular Music in Jamaica', in Copyright and Piracy (ed. Lionel Bently, Jennifer Davis, and Jane C. Ginsburg), pp. 357-73, Cambridge: Cambridge University Press.

Tyle, Chris (2014), 'Mood Indigo (1930)' (accessed October 1), http://www.jazzstandards.com/compositions-1/moodindigo.htm.

Van de Leur, Walter (2002), Something to Live For: The Music of Billy Strayhorn, Oxford: Oxford University Press.

Whyton, Tony (2013), Jazz Icons: Heroes, Myths and the Jazz Tradition, Cambridge: Cambridge University Press. 